Review

\title{
Review on PACAP-Induced Transcriptomic and Proteomic Changes in Neuronal Development and Repair
}

\author{
Adam Rivnyak, Peter Kiss, Andrea Tamas, Dorottya Balogh and Dora Reglodi * \\ Department of Anatomy, MTA-PTE PACAP Research Team, Neuroscience Centre, University of Pecs \\ Medical School, 7624 Pécs, Hungary; rivnyakadam@gmail.com (A.R.); peter.kiss@aok.pte.hu (P.K.); \\ andreatamassz@gmail.com (A.T.); baloghdorottya333@gmail.com (D.B.) \\ * Correspondence: dora.reglodi@aok.pte.hu; Tel.: +36-72-536-000; Fax: +36-72-536-393
}

Received: 31 January 2018; Accepted: 26 March 2018; Published: 29 March 2018

\begin{abstract}
Pituitary adenylate cyclase activating polypeptide (PACAP) is a neuropeptide with widespread occurrence and diverse biological effects. Among its several different effects, of special importance is the action of PACAP on neuronal proliferation, differentiation and migration, and neuroprotection. The neuroprotective mechanism of PACAP is both direct and indirect, via neuronal and non-neuronal cells. Several research groups have performed transcriptomic and proteomic analysis on PACAP-mediated genes and proteins. Hundreds of proteins have been described as being involved in the PACAP-mediated neuroprotection. In the present review we summarize the few currently available transcriptomic data potentially leading to the proteomic changes in neuronal development and protection. Proteomic studies focusing on the neuroprotective role of PACAP are also reviewed and discussed in light of the most intriguing and promising effect of this neuropeptide, which may possibly have future therapeutic potential.
\end{abstract}

Keywords: PACAP; neuropeptide; development; neurotrophic; neuroprotective

\section{General Overview}

Pituitary adenylate cyclase activating polypeptide (PACAP) is a neuropeptide with widespread occurrence and diverse biological effects [1,2]. PACAP occurs at highest concentrations in the nervous system, where it functions as a neuromodulatory and neurotransmitter peptide. In the nervous system, PACAP acts, amongst others, on hypothalamic hormone release and hypothalamo-hypophyseal hormonal regulatory pathways [3,4], on central thermoregulatory and feeding routes [5-8], on neurogenesis [9] and on cognitive performance [10-12]. Of special importance is the action of PACAP on neuronal proliferation, differentiation and migration, whereby the peptide has significant effects in the development of the nervous system $[13,14]$. Several factors that are important during development are upregulated after injuries. Mechanisms driven by these factors are re-employed in post-injury recovery and regeneration $[15,16]$. In this regard, PACAP is also a neurotrophic factor that is upregulated in several types of neuronal pathological conditions [16]. This has been shown following nerve transection, neuronal inflammations, stroke and traumatic brain injury [16-18]. The protective action of endogenous PACAP is also supported by the increased vulnerability to various harmful stressors of mice lacking PACAP (PACAP gene knockout mice) [19]. A more severe injury has been described in PACAP knockout mice in models of cerebral ischemia [20], in spinal cord traumatic injury [21] and in retinal ischemia [22]. Not surprisingly, exogenous PACAP is a very potent neuroprotective agent, as proven by dozens of neuronal injury models, both in vitro and in vivo [16-18,23-25]. 
The neuroprotective mechanism of PACAP is both direct and indirect, via neuronal and non-neuronal cells $[14,18]$. PACAP acts through its specific $G$ protein-coupled PAC1 receptor, which only binds PACAP, and through the VPAC1 and VPAC2 receptors, which also bind the structurally related vasoactive intestinal peptide (VIP) with similar affinity $[26,27]$. The neuroprotective signaling is mediated mainly via the PACAP-specific PAC1 receptor [24,28], through which anti-apoptotic and regeneration-promoting effects are mediated. This also explains why the closely related VIP acting on VPAC1/2 receptors exerts less potent neuroprotective effects, while other members of the peptide family (secretin, glucagon) have no neuroprotective efficacy $[17,25,26,28]$. However, the involvement of VPAC receptors also seems to be important, mainly conveying anti-inflammatory actions of the peptide. Via receptorial mechanisms, PACAP stimulates cAMP/PKA- (cyclic adenosine monophosphate/protein kinase A) mediated signaling, and also PI3K-pathways (phosphoinositol 3 kinase) and calcium-regulated mechanisms [27,29]. In addition, PACAP transactivates growth factor-related pathways [30] and penetrates the cell membrane directly, through receptor-independent uptake [31]. By these pathways, PACAP regulates a network of signaling molecules involved in neuronal protection and repair.

Several research groups have performed transcriptomic and proteomic analysis on PACAP-mediated genes and proteins. Hundreds of proteins have been described as involved in the PACAP-mediated neuroprotection $[17,18,24,25]$. The aim of the present review is to summarize the limited transcriptomic data currently available which could potentially lead to the proteomic changes in neuronal development and protection. Proteomic studies focusing on the neuroprotective effect of PACAP will also be reviewed and discussed in light of the most intriguing and promising effect of this neuropeptide.

Figure 1 summarizes transcriptomic data obtained from adrenal gland-derived cell lines, such as PC12 pheochromocytoma cells, mouse adrenal gland cells (MAG) and bovine chromaffin cells (BCC). We concentrate on changes that were found to be more than 2-fold. Figure 2 summarizes transcriptomic changes in vivo, while Figure 3 those of in vitro and in vivo proteomic studies. Obviously, it does not preclude smaller changes that can also be important during neuronal development and repair, but a complete list is beyond the scope of this present review. Transcriptomic and proteomic changes can be grouped according to several aspects. Focusing on neuronal development and neuroprotection, altered genes are involved in cellular defense, stress-related pathways, differentiation, apoptosis, cell cycle, angiogenesis and cellular homeostasis. The summarized changes are discussed in light of the known neurotrophic and neuroprotective effects of the peptide, and some marked changes with known neuronal functions are highlighted [32-46]. 


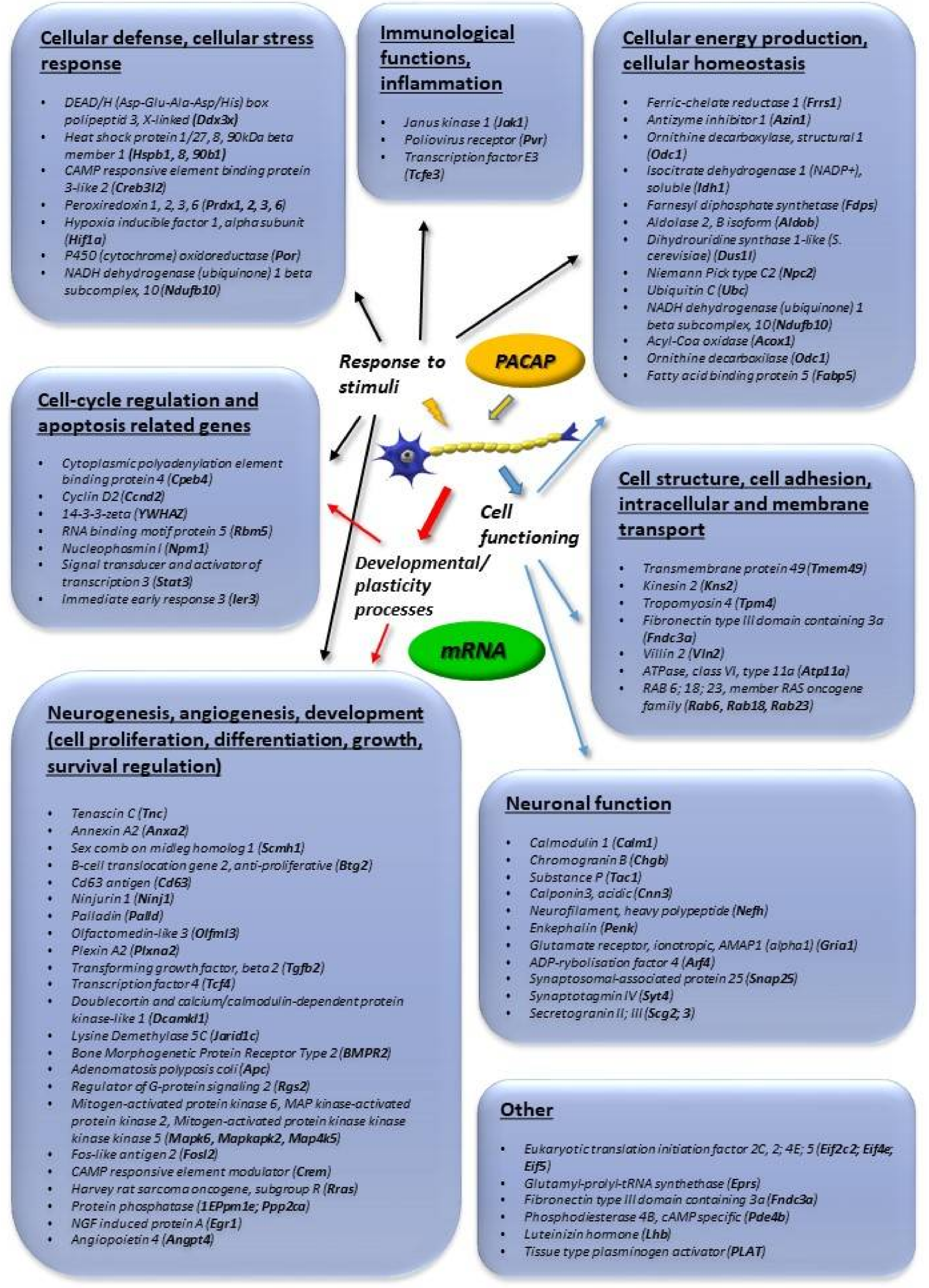

Figure 1. Main in vitro transcriptomic changes induced by pituitary adenylate cyclase activating polypeptide (PACAP). Genes upregulated more than 2-fold are listed. The data in the figure come from the references: [32-35,46]. 


\section{Immunological} functions, inflammation

- Interieukin 1 beta; 6; 22 (IL1b, $(L-6, \| 22) \uparrow$

- Chemokine C-C motif ligand 2 (Ccl2) $\uparrow$

- Cathelicidin antimicrobial peptide (Camp) $\uparrow$

- Tumor necrosis factor-aipho (TNF-a) $\downarrow$

- Inducibie nitric oxide synthase 2 (Nos2) $\downarrow$

- Macrophage inflammatory protein-1 aipha (MIP-1a) $\downarrow$

- COMM domain containing 7 (COMMD7) $\downarrow$

\section{Cellular defense, cellular} stress response

- Heot shock protein $1 /$ hsp27 (Hspb1) $\uparrow$

- Alpha hemoglobin stabilizing protein (Ahsp) $\uparrow$

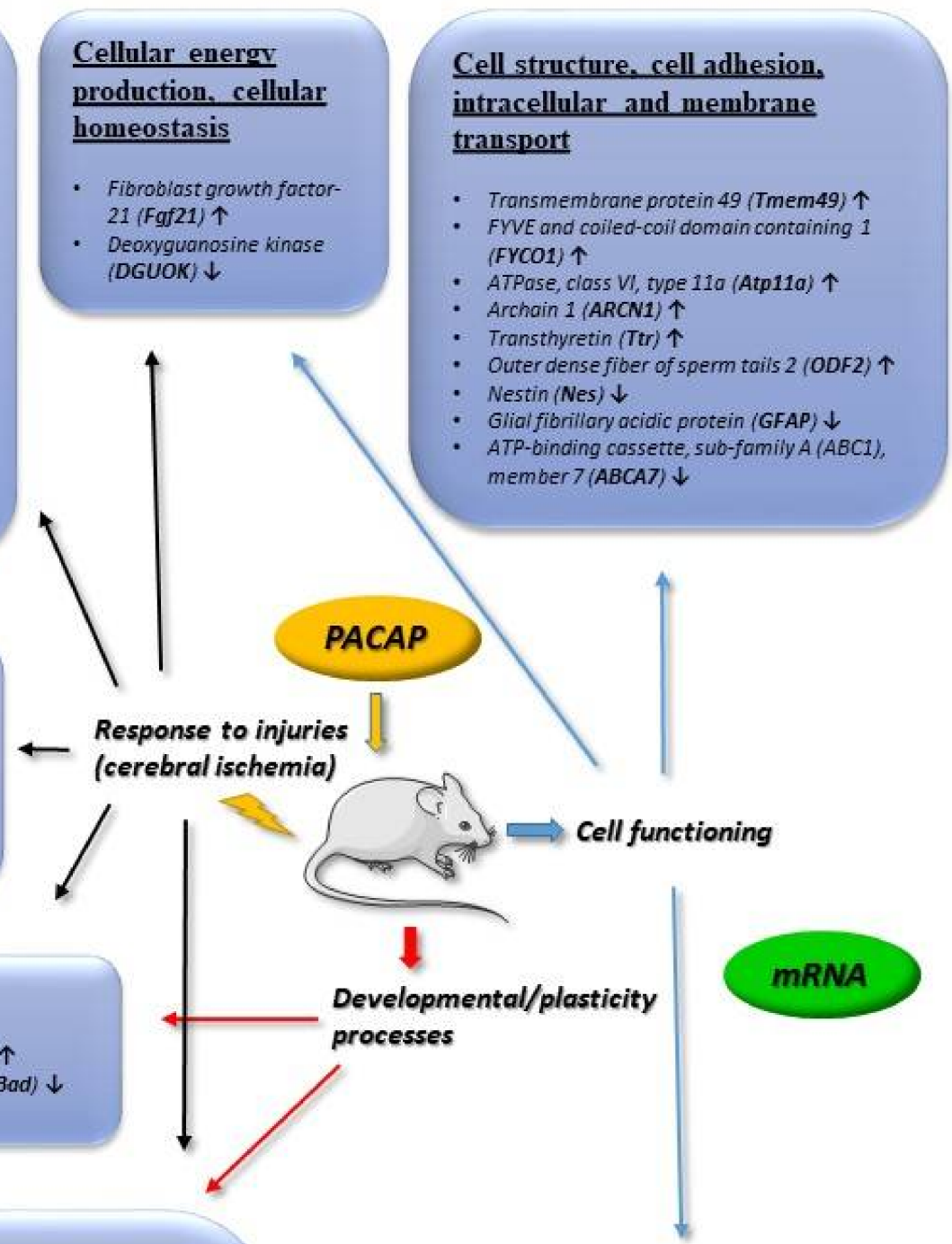

\section{Neurogenesis, development (cell} proliferation, differentiation, growth, survival regulation)

- Brain-derived neurotrophic factor (Bdnf) $\uparrow$

- Annexin A2 (Anxa2) $\uparrow$

- Calcium/calmodulin-dependent protein kinase ID (CAMK1D) $\uparrow$

- Cd63 antigen (Cd63) $\uparrow$

- Fos-like antigen 2 (Fos/2) $\uparrow$

- T-6ox 22(TBX22) $\uparrow$

- Neurogenic differentiation factor 1 (Neurod1) $\uparrow$

- Kruppel-like factor 12 (KLF12) $\uparrow$

- Insulin-like growth factor 1 (Igf1) $\uparrow$

- S100 calcium binding protein A5 (S100a5) $\uparrow$

- Fibroblast growth factor-21 (Fgf21) $\uparrow$

- Short stature homeobox 2 (SHOX2) $\uparrow$

- Prolactin receptor (Prir) $\downarrow$

\section{Neuronal function}

- Gamma-aminobutyric acid (GABA) A receptor 6(Gabra6) $\uparrow$

- Amyloid beto (A4) precursor protein (APP) $\uparrow$

- Tryptophan hydroxylase 2 (Tph2) $\downarrow$

- Solute carrier family 6 member (4SIc6a4) $\downarrow$

\section{Other}

- Adenosine deaminase domain containing 2 (ADAD2) $\uparrow$

- Origin recognition complex, subunit $3(O R C 3) \uparrow$

- PHD finger protein 20-iike 1 (PHF20L1) $\uparrow$

- DEAD box polypeptide 43 (DDX43) $\downarrow$

- Maestro heat-like repeat family member 8 (MROH $\$$ ) $\downarrow$

- Phosphate regulating endopeptidase homolog, X-linked $($ PHEX) $\downarrow$

Figure 2. Main in vivo transcriptomic changes induced by PACAP. Arrows indicate main up or downregulated genes. The data in the figure come from the references: $[32,33,36,37]$. 
Cellular energv production. cellular homeostasis

- Cytochrome Coxidase subunit5A $\uparrow$

- Alphaenolase $\uparrow$

- Enolase 2, gammaneural $\uparrow$

- Aldolase 1, A isoform $\uparrow$

- Aspartate aminotransferase $\uparrow$

- Phosphog lycerate mutase $1 \uparrow$

- Pyruvate kinase, muscle isoform M1 $\uparrow$

- Aconitase $2 \uparrow$

- Malate dehydrogenase 1, NAD isoform $\uparrow$

- Malate dehydrogenase $\downarrow$

- Glyceraldehyde-3-phosphate dehydrogenase $\downarrow$

- Prohibitin $\downarrow$

- ATP synthase $\downarrow$

\section{Cellular defense, cellular stress} response

- Hsp271

- Stress-induced phosphoprotein $1 \uparrow$

- Peroxiredoxin-6 $\uparrow$

- Gluthation-S-transferaseMu $1 \uparrow$

- PARK-7 $\uparrow$

- Hsp60 precursor $\downarrow$

- Hsp90-beta $\downarrow$

- Gluthatione-S-transferasealpha $3 \downarrow$

\section{Cell-cycle regulation and} apoptoses related genes

- Peptydilprolyl isomerase A $\uparrow$

- Caspase- 3 p17 subunit $\downarrow$

- GTPaseran $\downarrow$

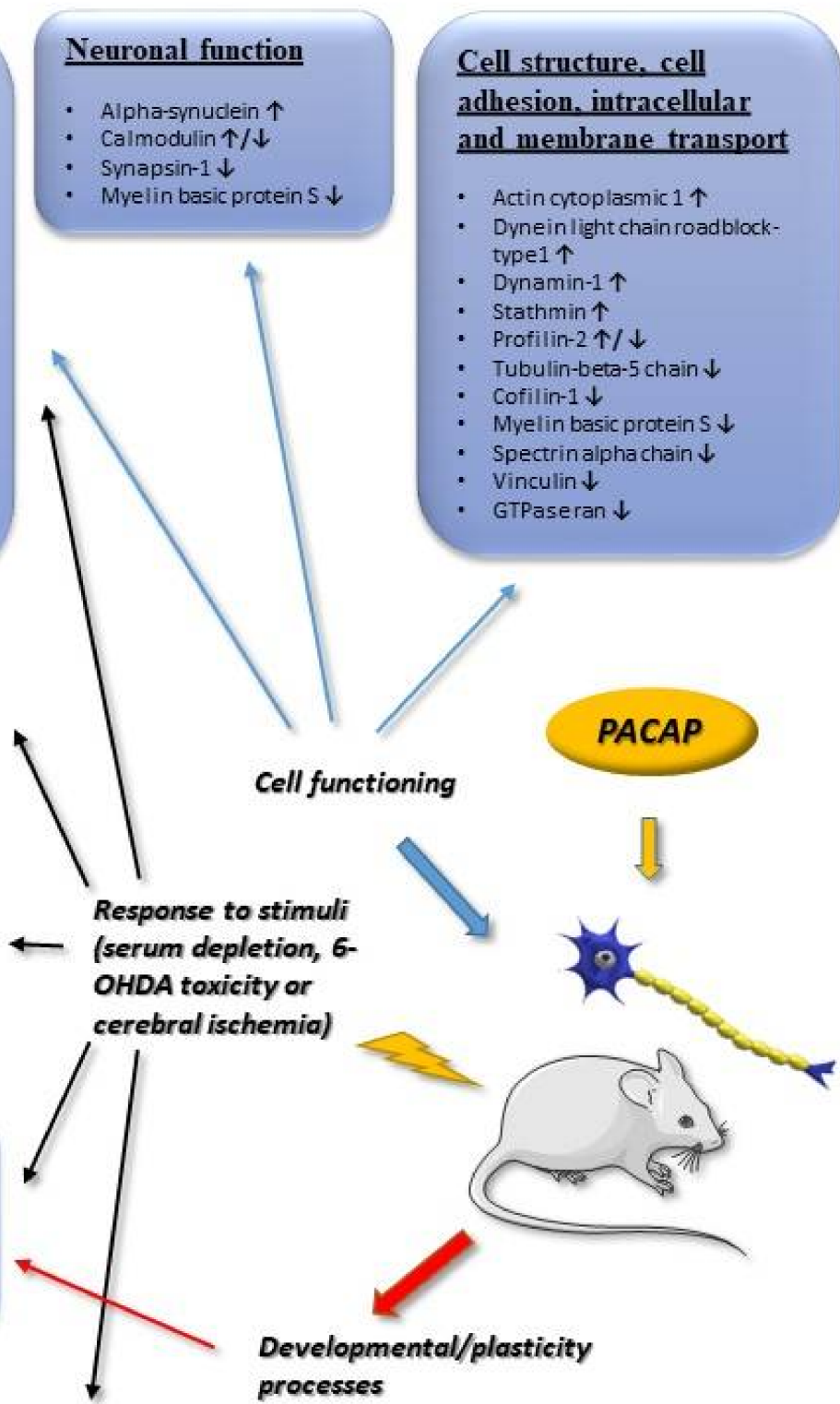

\section{Neurogenesis, development (cell proliferation, differentiation, growth. survival regulation)}
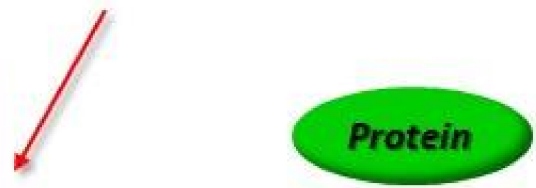

- EndophilinA2 $\uparrow$

- Phosphatydetanolam ine-binding protein $1 \uparrow$

- Growth factor receptor-bound protein $2 \uparrow$

- Collapsin Response Mediztor Protein $2 \uparrow$

- Nucleoside dihosphate kinaseA and/or B $\uparrow$

- Nucleoside diphosphatekinase $\downarrow$

- Dihydropyrimidinase-related protein $2 \downarrow$

- Cofilin-1 $\downarrow$

- Vacuolar ATP synthase subunitE1 $\downarrow$

- Tubb2 protein $\downarrow$

- Prohibitin $\downarrow$

\section{Other}

- Secretin receptor $\uparrow$

- HistoneH1 domain $\uparrow$

- Leucine-rich repeat containing $9 \uparrow$

- Peptydilprolyl isomeraseA $\uparrow$

- $60 S$ ribosomal protein $L 18 a \downarrow$

- Ubiquitinc-terminal hydrolase isozymeL1 $\downarrow$

Figure 3. Main in vivo and in vitro proteomic changes induced by PACAP. Arrows indicate main up or downregulated genes. The data in the figure come from the references: $[37-41,43,44,46]$. Abbreviation: 6-OHDA (6-Hydroxydopamine). 


\section{Involvement of PACAP in Neuronal Developmental Processes}

PACAP has been described in the proliferation and differentiation of various neuronal cell lines, such as cortical neuroblasts [47], cerebellar granule cells [48,49], retinoblasts [50,51], sympathetic neuroblasts [52] and olfactory neuroblasts [53], detailed transcriptomic studies are available on adrenal cells. Data from chromaffin cells (PC12 pheochromocytoma cells) have been reviewed by Samal et al. [32], providing a thorough meta-analysis of PACAP-regulated genes.

A well-known PACAP-signaling target is the mitogen-activated protein kinase (MAPK) family with downstream CREB (cAMP response element binding protein) activation [24]. Transcriptomic data support this, as several Ras/MAP kinases and CREB-like proteins and modulators were strongly upregulated upon PACAP exposure (Figure 1). Another target of PACAP signaling is the calcium calmodulin pathway, members of which have also been shown to be upregulated upon PACAP exposure, as reported by in vitro and in vivo transcriptomic as well as proteomic studies (Figures 1-3).

Several genes influenced by PACAP are involved in cell cycle regulation and cell proliferation. Transcriptomic data have revealed that PACAP upregulates members of the cell cycle regulator family cyclin (e.g., cyclinD2), and other complex factors that are part of the mitogenic signaling, such as Jak1 (janus kinase 1) and Stat3 (signal transducer and activator of transcription 3) [54,55] (Figure 1). These mitogenic effects are important in PACAP's effects in neuronal proliferation, as it has been described in cortical neuroblasts [47], neural/glial progenitor cells [56], chicken neuroblasts [57] and cerebellar granule cells [58]. It seems that this function is dependent on receptor subtype expression and the neuronal differentiation stage during normal as well as tumorous development, since PACAP not only stimulates proliferation but can also be antimitotic and inhibit proliferation as it stimulates various signaling pathways depending on the receptor splice variant expression [52]. A receptor switch has been reported in cortical neuroblasts, determining the switch from mitogenic to anti-mitogenic actions depending on the neuronal differentiation stage [59]. A further modifying factor can be the tumorous nature of the blast cells, as opposite effects have been described in some malignant tumors of neuronal blast cells, such as medulloblastoma where PACAP inhibited proliferation [60] and in retinoblastoma, where decreased cell viability was observed upon PACAP treatment [61].

During brain development, PACAP is involved not only in the proliferation, but also in migration and differentiation of developing neuronal cells. Numerous transcription factors involved in neuronal differentiation are also upregulated by PACAP. Among them, transforming growth factor beta (TGFbeta), nerve growth factor-induced protein A (Egr1), brain derived neurotrophic factor (BDNF), fibroblast growth factor (FGF21), insulin-like growth factor (Igf1) and bone morphogenic protein receptor type 2 are very important factors during brain development [62-67] (Figures 1 and 2). In neuronal differentiation, PACAP is known to be involved in axonal growth cone development and axonal elongation [68], in neuronal migration [69,70] and in neuronal patterning [71]. Transcriptomic data have revealed, for example, an upregulation of plexin A2 (Figure 1), which is important in axon elongation [72]. PACAP also influences synaptogenesis, possibly via the upregulated SNAP-25/SNARE complex (soluble NSF(N-ethylmaleimide-sensitive factor attachment protein, and its receptor) [73] and synaptostagmin 4 [74] in addition to AMPA receptor 1 ( $\alpha$-amino-3-hydroxy-5-methyl-4-isoxazolepropionic acid) (Figure 1). Neurofilament polypeptide and calponin 3, parts of the neuronal cytoskeleton [75,76], are also upregulated by PACAP (Figure 1). One of the genes showing most marked changes is tenascin $C$ (via annexin-2) (Figures 1 and 2), which is known to form a net around neurons during development and also in adulthood. The PACAP-induced elevation in tenascin $C$ and annexin-2 may indicate a significant involvement of PACAP in neuronal network building [77,78].

Numerous experimental data show that PACAP is involved in the normal development of the brain. Most data are available from the cerebellum, where PACAP regulates cell migration, proliferation and differentiation of developing granular cells [79]. Layer-specific signaling has been mapped for PACAP during the development of cerebellar neurons [80]. PACAP is an important stop signal during the migration of cells from the external to internal granule layer [79]. The involvement of PACAP in cerebellar development has been studied not only in rodents, but also in monkeys [81]. 
During development, well-orchestrated programmed cell death plays a major role in the final cell composition of the brain. One of the most intensively studied effects of PACAP is apoptosis. PACAP influences several genes involved in apoptosis, resulting in numerous changes in the apoptotic signaling, initiation and execution. Among others, $14-3-3-\zeta$, upregulated by PACAP, negatively regulates apoptosis by binding and inactivating the pro-apoptotic bad and bax proteins [82] (Figures 2 and 3). Transcriptomic studies have also shown the down-regulation of caspase and bad by PACAP, also confirmed by several proteomic studies (Figures 2 and 3). A large amount of data shows the influence of PACAP on apoptosis during cerebellar development under normal circumstances [83]. Several further transcriptomic and proteomic changes prove the involvement of PACAP in neuronal development that is evidenced from experimental data in cell lines and from in vivo animal studies. Furthermore, data indicate a significant involvement of PACAP in neuronal network building. As PACAP is an important regulator of neuronal development, it is not surprising that several developmental malformations have been attributed to dysregulation of PACAP-mediated signaling. Disturbance of PACAP expression in PACAP gene deficient mice has been associated with irregular dendritic arborization [84], disturbed cerebellar development [85], alterations in ectomesenchymal differentiation in facial development $[86,87]$.

PACAP also influences development of glial cells. PACAP stimulates the proliferation of oligodendrocytes but delays their maturation [88], and so it is part of the myelination processes in the central nervous system, further confirmed by the upregulated plexin A2 gene (Figure 1), which is involved in myelination processes [89]. PACAP also affects astrogliogenesis and differentiation [14,90]. Interestingly, while PACAP promotes differentiation of astroglial cells under normal developmental circumstances [58], it inhibits proliferation of glioblastoma cells [91]. The third major glial cell type is microglia, the origin of which is mesodermal, in contrast to the neuroectodermal origin of all other cells in the central nervous system. In spite of this different origin, PACAP seems to also play a role in the differentiation and function of microglial cells [92].

\section{Neuroprotective Effects of PACAP}

Transcriptomic and proteomic studies also show that PACAP is an important regulator of normal neuronal functioning, even after development. It functions as a neurotransmitter and neuromodulator [34] and affects glial functions [14]. PACAP affects several physiological actions in the adult brain and is involved in complex behavioral processes, such as feeding, motor functions and thermoregulation [2,3,5,24]. PACAP is also involved in cognitive performance, fear and anxiety $[12,14]$. Not surprisingly, adult PACAP knockout mice display several abnormalities. The main shortcoming of using knockout mice is that the lack of PACAP induces several compensatory pathways, which can partially or totally compensate for the lack of the neuropeptide [93] and so data might be misleading. Lack of a symptom in the knockout mice does not necessarily mean that the peptide is not involved in this process under normal circumstances, when compensatory pathways are not involved. In contrast, when an alteration is found in the gene deficient mice, it makes it probable that the peptide plays a significant role in the regulation of that process. Although the morphological differences in PACAP gene deficient mice seem to be subtle, several'functional disturbances have been described in mice lacking endogenous PACAP [19,94]. These alterations could be caused by biochemical and cell signaling differences due to the lack of endogenous PACAP expression [94,95]. For example, altered stress-coping reactions have been described in PACAP heterozygous animals [96,97], altered psychomotor behavior [98] and decreased cognitive functions [99].

Of special importance is the observation that PACAP-regulated pathways are essential in neuroprotective processes as part of the endogenous protective machinery as a cell stress-responsive neuropeptide. This is evidenced by both in vitro and in vivo observations. In vitro, PACAP upregulates several important genes and proteins involved in cellular protection against various harmful stimuli. For example, PACAP has been shown to be protective against toxicity induced by several substances, 
such as ethanol, nicotine [23], ceramide [69,100], 6-hydroxydopamine [101], the HIV envelope protein [102] and cisplatin [103]. The strong neuroprotective property of PACAP can also be observed in vivo in several different models of neuronal injury. Among others, neuroprotective actions have been shown in excitotoxic injuries [104], 6-hydroxydopamine- [25], $\beta$-amyloid- [105] and ischemia-induced injuries [106]. The in vivo neuroprotective action of PACAP can be observed when the peptide is given exogenously and also in knockout mice reflecting the endogenous function of the peptide. Given the importance of PACAP in neuronal protection and repair, it is not surprising that mice lacking endogenous PACAP are more vulnerable to different stressors and injuries [19]. The increased sensitivity of PACAP knockout mice has been demonstrated in cerebral and retinal ischemia [20,22], in delayed axonal regeneration [107] and in paraquat-induced model of Parkinson's disease [108].

PACAP has long been known as a potent in vivo neuroprotective peptide when administered in a variety of neuronal lesions [16]. PACAP was first described as protecting hippocampal neurons from death in a model of global cerebral ischemia [109], later followed by studies showing the neuroprotective efficacy of PACAP in focal cerebral ischemia induced by permanent or transient middle cerebral artery occlusion $[110,111]$. Importantly, the peptide is neuroprotective even if the administration follows $4 \mathrm{~h}$ after the induction of stroke [110], indicating a relatively wide therapeutic window for PACAP's actions. These studies have later been confirmed by several research groups, in both rats and mice. Ohtaki and coworkers have shown that the increased infarct size in PACAP knockout mice can be compensated by exogenous PACAP [20]. The neuroprotective effects of PACAP have been described not only in models of ischemic injuries, but also in neurodegenerative diseases [17], such as models of Parkinson's disease [25,112], striatal model of Huntington's disease [113] or spinobulbar muscular atrophy [114] and also in traumatic brain injury [115]. Gasperini and colleagues have studied the proteome of diverse brain areas after PACAP injection [39] (Figure 3). They found that PACAP is involved in assorted molecular processes that may also be important during neuronal protection and regeneration, such as synaptic plasticity, cellular differentiation, proteins of apoptotic cascades and stress pathways.

Investigating the in vivo neuroprotective action of PACAP, transcriptomic and proteomic studies have mainly focused on ischemic injuries. Hori and coworkers have analyzed in detail the alterations after middle cerebral artery occlusion-induced cerebral ischemia [37,116] (Figures 2 and 3). They have described several changes that can be additive factors to exert protective effects in cerebral ischemic injuries. Dejda and colleagues [36] have analyzed a number of genes associated with the actions of PACAP, mainly involved in apoptosis and inflammation regulation, cell signaling and edema formation (Figure 2). Chen and coworkers have detected a number of genes altered in the early and late phases of cerebral infarct, using the same rat model [117] (Figure 2). They found that more genes were upregulated in the later phase of post-cerebral artery occlusion, than in the early phase, suggesting a more important protective role of PACAP in later phases of cerebral ischemia. Several of the PACAP-responsive transcripts have roles in neuronal processes, neuronal repair and plasticity. In addition to the developmental factors mentioned above, ninjurin, which is involved in axonal repair [118], has been shown to be upregulated after PACAP treatment (Figure 1). Brifault and coworkers [119] have analyzed the transcriptome after middle cerebral artery occlusion and PACAP-producing stem cell transplantation into the ventricular system. Their analysis showed that PACAP is involved in several regulatory pathways, such as chemotactic and inflammatory networks, and this may induce the phenotypic change in the microglial population towards neuroprotection [119]. Another research group has analyzed ischemic core and penumbra areas separately by transcriptomic and proteomic approaches $[37,100]$. They have identified several groups of genes and proteins to be differentially altered after the induction of cerebral ischemia. Altogether, transcriptomic and proteomic data confirm the involvement of anti-apoptotic and anti-inflammatory pathways in the PACAP-induced reduction of lesion size and post-injury repair and regeneration. For example, heat shock proteins and peroxiredoxin, with important functions in cellular stress-response [120,121], are upregulated by PACAP, as well as protective factors PARK7 and gluthathion $S$-transferase $[122,123]$ 
(Figures 1-3). Changes in factors involved in apoptotic pathways, inflammation, cellular defense and metabolism have been described by all these above-mentioned studies, with some differences probably due to different animal strain/source as well as the different time-window after the insult or the exact brain region analyzed. For example, Chen and co-workers analyzed brain samples 1 and $24 \mathrm{~h}$ after stroke, while Hori and co-workers 6 and $24 \mathrm{~h}$ after the induction of ischemia $[37,117]$. In contrast, Brifault and colleagues performed transcriptomic analysis 7 and 14 days after stroke [119]. Acute changes can be represented by $1 \mathrm{~h}$ data, samples obtained $6 \mathrm{~h}$ after stroke induction already a sub-acute phase, while data obtained 7 or 14 days after stroke already reflect regenerative changes. From minutes to weeks after the ischemic event, different processes play a major role in the ischemic cascade, like neuroprotection, inflammation followed by tissue repair and plasticity, naturally reflected also in the transcriptomic and proteomic changes [124]. In addition, numerous transcriptomic differences have been revealed between ischemic core and penumbra regions, the size of which gradually changes over time, further influencing the time-course and region-specific transcriptomic and proteomic alterations. Therefore, direct comparison of data obtained by different research groups using different experimental paradigms is not possible, but their main findings point to the involvement of PACAP in both acute and chronic responses after an ischemic insult and support the neuroprotective efficacy of the peptide.

In conclusion, the long-known neuroprotective effects of PACAP are supported by numerous transcriptomic and proteomic data, further indicating the involvement of PACAP in synaptic plasticity, neuronal growth and differentiation, apoptosis and inflammation and axonal growth. These data shed more light on the neuroprotective action of the peptide shown in several different models of neuronal injuries. Recent results indicate that this effect of PACAP is not only present in animal models but is also implicated in human diseases, in acute and chronic neuronal pathological conditions, and endogenous decline of the peptide can indicate neuronal degeneration [11]. Due to its human relevance, the therapeutic and/or diagnostic value of PACAP is gaining more importance, and thus, more detailed mechanistic approach is necessary in various neuronal injury models. The strong evidence for the neuroprotective effects of PACAP makes it a good candidate for future drug development in ischemic conditions and neurodegenerative diseases. Interestingly, however, closest to the therapeutic use is an antibody against PAC1 receptor that is already under clinical trial for treatment of migraine attacks, based on the effect of PACAP via PAC1 receptor in triggering migraine-type headaches [125]. Yet, this can lead to the blockade of various other, beneficial pathways induced by PACAP, as outlined in the present review. This calls for the necessity of further transcriptomic and proteomic studies that can help to reveal possible effects of future PACAP-based treatments as well as side-effects of blocking PACAP-signaling.

Acknowledgments: 2017-1.2.1-NKP-2017-00002; GINOP-2.3.2-15-2016-00050 “PEPSYS", MTA-TKI 14016, NKFIH K119759, 115874; EFOP-3.6.2-16-2017-00008: The role of neuro-inflammation in neurodegeneration: from molecules to clinics Neuroscience Centre of Pecs. The authors thank Brian K. Lucas for his diligent proofreading of this paper.

Conflicts of Interest: The authors declare no conflict of interest.

\section{References}

1. Jolivel, V.; Basille, M.; Aubert, N.; de Jouffrey, S.; Ancian, P.; Le Bigot, J.F.; Noack, P.; Massonneau, M.; Fournier, A.; Vaudry, H.; et al. Distribution and functional characterization of pituitary adenylate cyclase-activating polypeptide receptors in the brain of non-human primates. Neuroscience 2009, 160, $434-451$. [CrossRef] [PubMed]

2. Pirger, Z.; Krajcs, N.; Kiss, T. Occurrence, distribution, and physiological function of pituitary adenylyl cyclase-activating polypeptide in invertebrate species. In Pituitary Adenylate Cyclase Activating Polypeptide —PACAP; Reglodi, D., Tamas, A., Eds.; Springer: Cham, Switzerland, 2016; pp. 19-31. 
3. Egri, P.; Fekete, C.; Denes, A.; Reglodi, D.; Hashimoto, H.; Fulop, B.D.; Gereben, B. Pituitary adenylate cyclase-activating polypeptide (PACAP) regulates the hypothalamo-pituitary-thyroid (HPT) axis via type 2 deiodinase in male mice. Endocrinology 2016, 157, 2356-2366. [CrossRef] [PubMed]

4. Kanasaki, H.; Oride, A.; Tselmeg, M.; Sukhbaatar, U.; Kyo, S. Role of PACAP and its PACAP type I receptor in the central control of reproductive hormones. In Pituitary Adenylate Cyclase Activating Polypeptide_PACAP, Reglodi, D., Tamas, A., Eds.; Springer: Cham, Switzerland, 2016; pp. 375-387.

5. Garami, A.; Pakai, E.; Rumbus, Z.; Solymar, M. The role of pacap in the regulation of body temperature. In Pituitary Adenylate Cyclase Activating Polypeptide_PACAP; Springer: Cham, Switzerland, 2016; pp. $239-257$.

6. Banki, E.; Kovacs, K.; Nagy, D.; Juhasz, T.; Degrell, P.; Csanaky, K.; Kiss, P.; Jancso, G.; Toth, G.; Tamas, A. Molecular mechanisms underlying the nephroprotective effects of PACAP in diabetes. J. Mol. Neurosci. 2014, 54, 300-309. [CrossRef] [PubMed]

7. Sekar, R.; Wang, L.; Chow, B.K. Central control of feeding behavior by the secretin, PACAP, and glucagon family of peptides. Front. Endocrinol. 2017, 8, 18. [CrossRef] [PubMed]

8. Hurley, M.M.; Maunze, B.; Block, M.E.; Frenkel, M.M.; Reilly, M.J.; Kim, E.; Chen, Y.; Li, Y.; Baker, D.A.; Liu, Q.-S. Pituitary adenylate-cyclase activating polypeptide regulates hunger-and palatability-induced binge eating. Front. Neurosci. 2016, 10, 383. [CrossRef] [PubMed]

9. Matsumoto, M.; Nakamachi, T.; Watanabe, J.; Sugiyama, K.; Ohtaki, H.; Murai, N.; Sasaki, S.; Xu, Z.; Hashimoto, H.; Seki, T. Pituitary adenylate cyclase-activating polypeptide (PACAP) is involved in adult mouse hippocampal neurogenesis after stroke. J. Mol. Neurosci. 2016, 59, 270-279. [CrossRef] [PubMed]

10. Pecoraro, V.; Sardone, L.M.; Chisari, M.; Licata, F.; Volsi, G.L.; Perciavalle, V.; Ciranna, L.; Costa, L. A subnanomolar concentration of pituitary adenylate cyclase-activating polypeptide (PACAP) pre-synaptically modulates glutamatergic transmission in the rat hippocampus acting through acetylcholine. Neuroscience 2017, 340, 551-562. [CrossRef] [PubMed]

11. Han, P.; Caselli, R.J.; Baxter, L.; Serrano, G.; Yin, J.; Beach, T.G.; Reiman, E.M.; Shi, J. Association of pituitary adenylate cyclase-activating polypeptide with cognitive decline in mild cognitive impairment due to Alzheimer disease. JAMA Neurol. 2015, 72, 333-339. [CrossRef] [PubMed]

12. Kirry, A.J.; Herbst, M.R.; Poirier, S.E.; Maskeri, M.M.; Rothwell, A.C.; Twining, R.C.; Gilmartin, M.R. Pituitary adenylate-cyclase activating-polypeptide (PACAP) signaling in the prefrontal cortex modulates cued fear learning, but not spatial working memory, in female rats. Neuropharmacology 2018, 133, 145-154. [CrossRef] [PubMed]

13. Watanabe, J.; Seki, T.; Shioda, S. Pacap and neural development. In Pituitary Adenylate Cyclase Activating Polypeptide-PACAP; Springer: Cham, Switzerland, 2016; pp. 65-82.

14. Nakamachi, T.; Farkas, J.; Watanabe, J.; Ohtaki, H.; Dohi, K.; Arata, S.; Shioda, S. Role of PACAP in neural stem/progenitor cell and astrocyte: From neural development to neural repair. Curr. Pharm. Des. 2011, 17, 973-984. [CrossRef] [PubMed]

15. Waschek, J.A. Multiple actions of pituitary adenylyl cyclase activating peptide in nervous system development and regeneration. Dev. Neurosci. 2002, 24, 14-23. [CrossRef] [PubMed]

16. Somogyvari-Vigh, A.; Reglodi, D. Pituitary adenylate cyclase activating polypeptide: A potential neuroprotective peptide. Curr. Pharm. Des. 2004, 10, 2861-2889. [CrossRef] [PubMed]

17. Reglodi, D.; Kiss, P.; Lubics, A.; Tamas, A. Review on the protective effects of PACAP in models of neurodegenerative diseases in vitro and in vivo. Curr. Pharm. Des. 2011, 17, 962-972. [CrossRef] [PubMed]

18. Shioda, S.; Nakamachi, T. PACAP as a neuroprotective factor in ischemic neuronal injuries. Peptides 2015, 72, 202-207. [CrossRef] [PubMed]

19. Reglodi, D.; Kiss, P.; Szabadfi, K.; Atlasz, T.; Gabriel, R.; Horvath, G.; Szakaly, P.; Sandor, B.; Lubics, A.; Laszlo, E. PACAP is an endogenous protective factor-Insights from PACAP-deficient mice. J. Mol. Neurosci. 2012, 48, 482-492. [CrossRef] [PubMed]

20. Ohtaki, H.; Nakamachi, T.; Dohi, K.; Aizawa, Y.; Takaki, A.; Hodoyama, K.; Yofu, S.; Hashimoto, H.; Shintani, N.; Baba, A. Pituitary adenylate cyclase-activating polypeptide (PACAP) decreases ischemic neuronal cell death in association with IL-6. Proc. Natl. Acad. Sci. USA 2006, 103, 7488-7493. [CrossRef] [PubMed]

21. Tsuchikawa, D.; Nakamachi, T.; Tsuchida, M.; Wada, Y.; Hori, M.; Farkas, J.; Yoshikawa, A.; Kagami, N.; Imai, N.; Shioda, S. The neuroprotective effect of endogenous PACAP on spinal cord injury. J. Mol. Neurosci. 2012, 48, 508-517. [CrossRef] [PubMed] 
22. Szabadfi, K.; Atlasz, T.; Kiss, P.; Danyadi, B.; Tamas, A.; Helyes, Z.; Hashimoto, H.; Shintani, N.; Baba, A.; Toth, G. Mice deficient in pituitary adenylate cyclase activating polypeptide (PACAP) are more susceptible to retinal ischemic injury in vivo. Neurotox. Res. 2012, 21, 41-48. [CrossRef] [PubMed]

23. Manavalan, S.; Getachew, B.; Manaye, K.F.; Khundmiri, S.J.; Csoka, A.B.; McKinley, R.; Tamas, A.; Reglodi, D.; Tizabi, Y. PACAP protects against ethanol and nicotine toxicity in SH-SY5Y cells: Implications for drinking-smoking co-morbidity. Neurotox. Res. 2017, 32, 8-13. [CrossRef] [PubMed]

24. Vaudry, D.; Falluel-Morel, A.; Bourgault, S.; Basille, M.; Burel, D.; Wurtz, O.; Fournier, A.; Chow, B.K.; Hashimoto, H.; Galas, L.; et al. Pituitary adenylate cyclase-activating polypeptide and its receptors: 20 years after the discovery. Pharmacol. Rev. 2009, 61, 283-357. [CrossRef] [PubMed]

25. Reglodi, D.; Renaud, J.; Tamas, A.; Tizabi, Y.; Socias, S.B.; del-Bel, E.; Raisman-Vozari, R. Novel tactics for neuroprotection in Parkinson's disease: Role of antibiotics, polyphenols and neuropeptides. Prog. Neurobiol. 2017, 155, 120-148. [CrossRef] [PubMed]

26. Vaudry, D.; Gonzalez, B.J.; Basille, M.; Yon, L.; Fournier, A.; Vaudry, H. Pituitary adenylate cyclase-activating polypeptide and its receptors: From structure to functions. Pharmacol. Rev. 2000, 52, 269-324. [PubMed]

27. Manecka, D.-L.; Boukhzar, L.; Falluel-Morel, A.; Lihrmann, I.; Anouar, Y. PACAP signaling in neuroprotection. In Pituitary Adenylate Cyclase Activating Polypeptide_PACAP; Springer: Cham, Switzerland, 2016; pp. 549-561.

28. Vaczy, A.; Reglodi, D.; Somoskeoy, T.; Kovács, K.; Lokos, E.; Szabo, E.; Tamas, A.; Atlasz, T. The protective role of PAC1-receptor agonist maxadilan in BCCAO-induced retinal degeneration. J. Mol. Neurosci. 2016, 60, 186-194. [CrossRef] [PubMed]

29. Ohtaki, H.; Shioda, S. PACAP regulation of inflammatory and free radical networks in neuronal and nonneuronal diseases. In Pituitary Adenylate Cyclase Activating Polypeptide-PACAP; Reglodi, D., Tamas, A., Eds.; Springer: Cham, Switzerland, 2016; pp. 671-690.

30. Moody, T.W.; Nuche-Berenguer, B.; Jensen, R.T. Vasoactive intestinal peptide/pituitary adenylate cyclase activating polypeptide, and their receptors and cancer. Curr. Opin. Endocrinol. Diabetes Obes. 2016, 23, $38-47$. [CrossRef] [PubMed]

31. Doan, N.-D.; Chatenet, D.; Létourneau, M.; Vaudry, H.; Vaudry, D.; Fournier, A. Receptor-independent cellular uptake of pituitary adenylate cyclase-activating polypeptide. Biochim. Biophys. Acta 2012, 1823, 940-949. [CrossRef] [PubMed]

32. Samal, B.; Gerdin, M.J.; Huddleston, D.; Hsu, C.-M.; Elkahloun, A.G.; Stroth, N.; Hamelink, C.; Eiden, L.E. Meta-analysis of microarray-derived data from PACAP-deficient adrenal gland in vivo and PACAP-treated chromaffin cells identifies distinct classes of PACAP-regulated genes. Peptides 2007, 28, 1871-1882. [CrossRef] [PubMed]

33. Eiden, L.E.; Samal, B.; Gerdin, M.J.; Mustafa, T.; Vaudry, D.; Stroth, N. Discovery of pituitary adenylate cyclase-activating polypeptide-regulated genes through microarray analyses in cell culture and in vivo. Ann. N. Y. Acad. Sci. 2008, 1144, 6-20. [CrossRef] [PubMed]

34. Ait-Ali, D.; Samal, B.; Mustafa, T.; Eiden, L.E. Neuropeptides, growth factors, and cytokines: A cohort of informational molecules whose expression is up-regulated by the stress-associated slow transmitter PACAP in chromaffin cells. Cell. Mol. Neurobiol. 2010, 30, 1441-1449. [CrossRef] [PubMed]

35. Samal, B.; Ait-Ali, D.; Bunn, S.; Mustafa, T.; Eiden, L.E. Discrete signal transduction pathway utilization by a neuropeptide (PACAP) and a cytokine (TNF- $\alpha$ ) first messenger in chromaffin cells, inferred from coupled transcriptome-promoter analysis of regulated gene cohorts. Peptides 2013, 45, 48-60. [CrossRef] [PubMed]

36. Dejda, A.; Seaborn, T.; Bourgault, S.; Touzani, O.; Fournier, A.; Vaudry, H.; Vaudry, D. PACAP and a novel stable analog protect rat brain from ischemia: Insight into the mechanisms of action. Peptides 2011, 32, 1207-1216. [CrossRef] [PubMed]

37. Hori, M.; Nakamachi, T.; Shibato, J.; Rakwal, R.; Shioda, S.; Numazawa, S. Unraveling the specific ischemic core and penumbra transcriptome in the permanent middle cerebral artery occlusion mouse model brain treated with the neuropeptide PACAP38. Microarrays 2015, 4, 2-24. [CrossRef] [PubMed]

38. Lebon, A.; Seyer, D.; Cosette, P.; Coquet, L.; Jouenne, T.; Chan, P.; Leprince, J.; Fournier, A.; Vaudry, H.; Gonzalez, B.J.; et al. Identification of proteins regulated by PACAP in PC12 cells by 2D gel electrophoresis coupled to mass spectrometry. Ann. N. Y. Acad. Sci. 2006, 1070, 380-387. [CrossRef] [PubMed]

39. Gasperini, L.; Piubelli, C.; Carboni, L. Proteomics of rat hypothalamus, hippocampus and pre-frontal/frontal cortex after central administration of the neuropeptide PACAP. Mol. Biol. Rep. 2012, 39, 2921-2935. [CrossRef] [PubMed] 
40. Maasz, G.; Pirger, Z.; Reglodi, D.; Petrovics, D.; Schmidt, J.; Kiss, P.; Rivnyak, A.; Hashimoto, H.; Avar, P.; Jambor, E.; et al. Comparative protein composition of the brains of PACAP-deficient mice using mass spectrometry-based proteomic analysis. J. Mol. Neurosci. 2014, 54, 310-319. [CrossRef] [PubMed]

41. Maasz, G.; Zrinyi, Z.; Reglodi, D.; Petrovics, D.; Rivnyak, A.; Kiss, T.; Jungling, A.; Tamas, A.; Pirger, Z. Pituitary adenylate cyclase-activating polypeptide (PACAP) has a neuroprotective function in dopamine-based neurodegeneration in rat and snail parkinsonian models. Dis. Model. Mech. 2017, 10, 127-139. [CrossRef] [PubMed]

42. Cabezas-Llobet, N.; Vidal-Sancho, L.; Masana, M.; Fournier, A.; Albrech, J.; Vaudry, D.; Xifró, X. Pituitary adenylate cyclase-activating polypeptide (PACAP) enhances hippocampal synaptic plasticity and improves memory performance in Huntington's disease. Mol. Neurobiol. 2018, 1-15. [CrossRef] [PubMed]

43. Hori, M.; Nakamachi, T.; Shibato, J.; Rakwal, R.; Tsuchida, M.; Shioda, S.; Numazawa, S. PACAP38 differentially effects genes and CRMP2 protein expression in ischemic core and penumbra regions of permanent middle cerebral artery occlusion model mice brain. Int. J. Mol. Sci. 2014, 15, 17014-17034. [CrossRef] [PubMed]

44. Fahrenkrug, J.; Hannibal, J.; Honore, B.; Vorum, H. Altered calmodulin response to light in the suprachiasmatic nucleus of PAC1 receptor knockout mice revealed by proteomic analysis. J. Mol. Neurosci. 2005, 25, 251-258. [CrossRef]

45. Waschek, J.A.; Baca, S.M.; Akerman, S. PACAP and migraine headache: Immunomodulation of neural circuits in autonomic ganglia and brain parenchyma. J. Headache Pain 2018, 19, 23. [CrossRef] [PubMed]

46. Ishido, M.; Masuo, Y. Transcriptome of pituitary adenylate cyclase-activating polypeptide-differentiated PC12 cells. Regul. Pept. 2004, 123, 15-21. [CrossRef] [PubMed]

47. Nicot, A.; DiCicco-Bloom, E. Regulation of neuroblast mitosis is determined by PACAP receptor isoform expression. Proc. Natl. Acad. Sci. USA 2001, 98, 4758-4763. [CrossRef] [PubMed]

48. Basille, M.; Gonzalez, B.; Leroux, P.; Jeandel, L.; Fournier, A.; Vaudry, H. Localization and characterization of PACAP receptors in the rat cerebellum during development: Evidence for a stimulatory effect of PACAP on immature cerebellar granule cells. Neuroscience 1993, 57, 329-338. [CrossRef]

49. Vaudry, D.; Gonzalez, B.; Basille, M.; Pamantung, T.; Fournier, A.; Vaudry, H. PACAP acts as a neurotrophic factor during histogenesis of the rat cerebellar cortex. Ann. N. Y. Acad. Sci. 2000, 921, 293-299. [CrossRef] [PubMed]

50. Dénes, V.; Czotter, N.; Lakk, M.; Berta, G.; Gábriel, R. PAC1-expressing structures of neural retina alter their PAC1 isoform splicing during postnatal development. Cell Tissue Res. 2014, 355, 279-288. [CrossRef] [PubMed]

51. Atlasz, T.; Vaczy, A.; Werling, D.; Kiss, P.; Tamas, A.; Kovacs, K.; Fabian, E.; Kvarik, T.; Mammel, B.; Danyadi, B. Protective effects of PACAP in the retina. In Pituitary Adenylate Cyclase Activating Polypeptide_PACAP; Springer: Cham, Switzerland, 2016; pp. 501-527.

52. Spengler, D.; Waeber, C.; Pantaloni, C.; Holsboer, F.; Bockaert, J.; Seeburg, P.H.; Journot, L. Differential signal transduction by five splice variants of the PACAP receptor. Nature 1993, 365, 170-175. [PubMed]

53. Lucero, M.T. Sniffing out a role for PACAP in the olfactory system. In Pituitary Adenylate Cyclase Activating Polypeptide—PACAP; Springer: Cham, Switzerland, 2016; pp. 483-499.

54. Yuan, Z.; Guan, Y.; Wang, L.; Wei, W.; Kane, A.B.; Chin, Y.E. Central role of the threonine residue within the $\mathrm{P}+1$ loop of receptor tyrosine kinase in Stat 3 constitutive phosphorylation in metastatic cancer cells. Mol. Cell. Biol. 2004, 24, 9390-9400. [CrossRef] [PubMed]

55. Kisseleva, T.; Bhattacharya, S.; Braunstein, J.; Schindler, C.W. Signaling through the JAK/Stat pathway, recent advances and future challenges. Gene 2002, 285, 1-24. [CrossRef]

56. Nishimoto, M.; Furuta, A.; Aoki, S.; Kudo, Y.; Miyakawa, H.; Wada, K. PACAP/PAC1 autocrine system promotes proliferation and astrogenesis in neural progenitor cells. Glia 2007, 55, 317-327. [CrossRef] [PubMed]

57. Erhardt, N.M.; Sherwood, N.M. PACAP maintains cell cycling and inhibits apoptosis in chick neuroblasts. Mol. Cell. Endocrinol. 2004, 221, 121-134. [CrossRef] [PubMed]

58. Nicot, A.; Lelievre, V.; Tam, J.; Waschek, J.A.; DiCicco-Bloom, E. Pituitary adenylate cyclase-activating polypeptide and sonic hedgehog interact to control cerebellar granule precursor cell proliferation. J. Neurosci. 2002, 22, 9244-9254. [PubMed] 
59. Yan, Y.; Zhou, X.; Pan, Z.; Ma, J.; Waschek, J.A.; DiCicco-Bloom, E. Pro-and anti-mitogenic actions of pituitary adenylate cyclase-activating polypeptide in developing cerebral cortex: Potential mediation by developmental switch of PAC1 receptor mRNA isoforms. J. Neurosci. 2013, 33, 3865-3878. [CrossRef] [PubMed]

60. Cohen, J.R.; Resnick, D.Z.; Niewiadomski, P.; Dong, H.; Liau, L.M.; Waschek, J.A. Pituitary adenylyl cyclase activating polypeptide inhibits gli1 gene expression and proliferation in primary medulloblastoma derived tumorsphere cultures. BMC Cancer 2010, 10, 676. [CrossRef] [PubMed]

61. Wojcieszak, J.; Zawilska, J.B. PACAP38 and PACAP6-38 exert cytotoxic activity against human retinoblastoma Y79 cells. J. Mol. Neurosci. 2014, 54, 463-468. [CrossRef] [PubMed]

62. Hegarty, S.V.; O'Keeffe, G.W.; Sullivan, A.M. Neurotrophic factors: From neurodevelopmental regulators to novel therapies for Parkinson's disease. Neural Regen. Res. 2014, 9, 1708-1711. [PubMed]

63. Harada, T.; Morooka, T.; Ogawa, S.; Nishida, E. ERK induces p35, a neuron-specific activator of Cdk5, through induction of Egr1. Nat. Cell Biol. 2001, 3, 453-459. [CrossRef] [PubMed]

64. Maisonpierre, P.C.; Belluscio, L.; Friedman, B.; Alderson, R.F.; Wiegand, S.J.; Furth, M.E.; Lindsay, R.M.; Yancopoulos, G.D. NT-3, BDNF, and NGF in the developing rat nervous system: Parallel as well as reciprocal patterns of expression. Neuron 1990, 5, 501-509. [CrossRef]

65. Kuroda, M.; Muramatsu, R.; Maedera, N.; Koyama, Y.; Hamaguchi, M.; Fujimura, H.; Yoshida, M.; Konishi, M.; Itoh, N.; Mochizuki, H.; et al. Peripherally derived FGF21 promotes remyelination in the central nervous system. J. Clin. Investig. 2017, 127, 3496-3509. [CrossRef] [PubMed]

66. Arsenijevic, Y.; Weiss, S. Insulin-like growth factor-I is a differentiation factor for postmitotic CNS stem cell-derived neuronal precursors: Distinct actions from those of brain-derived neurotrophic factor. J. Neurosci. 1998, 18, 2118-2128. [PubMed]

67. Bani-Yaghoub, M.; Felker, J.M.; Sans, C.; Naus, C.C. The effects of bone morphogenetic protein 2 and 4 (BMP2 and BMP4) on gap junctions during neurodevelopment. Exp. Neurol. 2000, 162, 13-26. [CrossRef] [PubMed]

68. Guirland, C.; Buck, K.B.; Gibney, J.A.; DiCicco-Bloom, E.; Zheng, J.Q. Direct cAMP signaling through G-protein-coupled receptors mediates growth cone attraction induced by pituitary adenylate cyclase-activating polypeptide. J. Neurosci. 2003, 23, 2274-2283. [PubMed]

69. Falluel-Morel, A.; Vaudry, D.; Aubert, N.; Galas, L.; Benard, M.; Basille, M.; Fontaine, M.; Fournier, A.; Vaudry, H.; Gonzalez, B.J. Pituitary adenylate cyclase-activating polypeptide prevents the effects of ceramides on migration, neurite outgrowth, and cytoskeleton remodeling. Proc. Natl. Acad. Sci. USA 2005, 102, 2637-2642. [CrossRef] [PubMed]

70. DiCicco-Bloom, E.; Lu, N.; Pintar, J.E.; Zhang, J. The PACAP ligand/receptor system regulates cerebral cortical neurogenesis. Ann. N. Y. Acad. Sci. 1998, 865, 274-289. [CrossRef] [PubMed]

71. Waschek, J.A.; Casillas, R.A.; Nguyen, T.B.; DiCicco-Bloom, E.M.; Carpenter, E.M.; Rodriguez, W.I. Neural tube expression of pituitary adenylate cyclase-activating peptide (PACAP) and receptor: Potential role in patterning and neurogenesis. Proc. Natl. Acad. Sci. USA 1998, 95, 9602-9607. [CrossRef] [PubMed]

72. Negishi, M.; Oinuma, I.; Katoh, H. Plexins: Axon guidance and signal transduction. Cell. Mol. Life Sci. 2005, 62, 1363-1371. [CrossRef] [PubMed]

73. Rizo, J.; Südhof, T.C. Snares and Munc18 in synaptic vesicle fusion. Nat. Rev. Neurosci. 2002, 3, $641-653$. [CrossRef] [PubMed]

74. Yoshihara, M.; Adolfsen, B.; Galle, K.T.; Littleton, J.T. Retrograde signaling by Syt 4 induces presynaptic release and synapse-specific growth. Science 2005, 310, 858-863. [CrossRef] [PubMed]

75. Flynn, K.C. The cytoskeleton and neurite initiation. Bioarchitecture 2013, 3, 86-109. [CrossRef] [PubMed]

76. Plantier, M.; Fattoum, A.; Menn, B.; Ben-Ari, Y.; Der Terrossian, E.; Represa, A. Acidic calponin immunoreactivity in postnatal rat brain and cultures: Subcellular localization in growth cones, under the plasma membrane and along actin and glial filaments. Eur. J. Neurosci. 1999, 11, 2801-2812. [CrossRef] [PubMed]

77. Giblin, S.P.; Midwood, K.S. Tenascin-C: Form versus function. Cell Adhes. Migr 2015, 9, 48-82. [CrossRef] [PubMed]

78. Chung, C.Y.; Murphy-Ullrich, J.E.; Erickson, H.P. Mitogenesis, cell migration, andloss of focal adhesions induced by tenascin-C interacting with its cell surfacereceptor, annexin II. Mol. Biol. Cell 1996, 6, 883-892. [CrossRef] 
79. Galas, L.; Benard, M.; Lebon, A.; Komuro, Y.; Schapman, D.; Vaudry, H.; Vaudry, D.; Komuro, H. Postnatal migration of cerebellar interneurons. Brain Sci. 2017, 7, 62. [CrossRef] [PubMed]

80. Raoult, E.; Benard, M.; Komuro, H.; Lebon, A.; Vivien, D.; Fournier, A.; Vaudry, H.; Vaudry, D.; Galas, L. Cortical-layer-specific effects of PACAP and tPA on interneuron migration during post-natal development of the cerebellum. J. Neurochem. 2014, 130, 241-254. [CrossRef] [PubMed]

81. Aubert, N.; Basille, M.; Falluel-Morel, A.; Vaudry, D.; Bucharles, C.; Jolivel, V.; Fisch, C.; de Jouffrey, S.; le Bigot, J.F.; Fournier, A.; et al. Molecular, cellular, and functional characterizations of pituitary adenylate cyclase-activating polypeptide and its receptors in the cerebellum of new and old world monkeys. J. Comp. Neurol. 2007, 504, 427-439. [CrossRef] [PubMed]

82. Liang, R.; Chen, X.Q.; Bai, Q.X.; Wang, Z.; Zhang, T.; Yang, L.; Dong, B.X.; Gao, G.X.; Gu, H.T.; Zhu, H.F. Increased 14-3-3 $\zeta$ expression in the multidrug-resistant leukemia cell line HL-60/VCR as compared to the parental line mediates cell growth and apoptosis in part through modification of gene expression. Acta Haematol. 2014, 132, 177-186. [CrossRef] [PubMed]

83. Allais, A.; Burel, D.; Roy, V.; Arthaud, S.; Galas, L.; Isaac, E.R.; Desfeux, A.; Parent, B.; Fournier, A.; Chapillon, P.; et al. Balanced effect of PACAP and FasL on granule cell death during cerebellar development: A morphological, functional and behavioural characterization. J. Neurochem. 2010, 113, 329-340. [CrossRef] [PubMed]

84. Yamada, K.; Matsuzaki, S.; Hattori, T.; Kuwahara, R.; Taniguchi, M.; Hashimoto, H.; Shintani, N.; Baba, A.; Kumamoto, N.; Yamada, K. Increased stathmin1 expression in the dentate gyrus of mice causes abnormal axonal arborizations. PLoS ONE 2010, 5, e8596. [CrossRef] [PubMed]

85. Allais, A.; Burel, D.; Isaac, E.R.; Gray, S.L.; Basille, M.; Ravni, A.; Sherwood, N.M.; Vaudry, H.; Gonzalez, B.J. Altered cerebellar development in mice lacking pituitary adenylate cyclase-activating polypeptide. Eur. J. Neurosci. 2007, 25, 2604-2618. [CrossRef] [PubMed]

86. Sándor, B.; Fintor, K.; Reglodi, D.; Fulop, D.; Helyes, Z.; Szántó, I.; Nagy, P.; Hashimoto, H.; Tamás, A. Structural and morphometric comparison of lower incisors in PACAP-deficient and wild-type mice. J. Mol. Neurosci. 2016, 59, 300-308. [CrossRef] [PubMed]

87. Farkas, J.; Sandor, B.; Tamas, A.; Kiss, P.; Hashimoto, H.; Nagy, A.D.; Fulop, B.D.; Juhasz, T.; Manavalan, S.; Reglodi, D. Early neurobehavioral development of mice lacking endogenous PACAP. J. Mol. Neurosci. 2017, 61, 468-478. [CrossRef] [PubMed]

88. Lee, M.; Lelievre, V.; Zhao, P.; Torres, M.; Rodriguez, W.; Byun, J.Y.; Doshi, S.; Ioffe, Y.; Gupta, G.; de los Monteros, A.E.; et al. Pituitary adenylyl cyclase-activating polypeptide stimulates DNA synthesis but delays maturation of oligodendrocyte progenitors. J. Neurosci. 2001, 21, 3849-3859. [PubMed]

89. Vincze, A.; Reglodi, D.; Helyes, Z.; Hashimoto, H.; Shintani, N.; Abraham, H. Role of endogenous pituitary adenylate cyclase activating polypeptide (PACAP) in myelination of the rodent brain: Lessons from PACAP-deficient mice. Int. J. Dev. Neurosci. 2011, 29, 923-935. [CrossRef] [PubMed]

90. Vallejo, M. PACAP signaling to dream: A camp-dependent pathway that regulates cortical astrogliogenesis. Mol. Neurobiol. 2009, 39, 90-100. [CrossRef] [PubMed]

91. Vertongen, P.; Camby, I.; Darro, F.; Kiss, R.; Robberecht, P. VIP and pituitary adenylate cyclase activating polypeptide (PACAP) have an antiproliferative effect on the T98G human glioblastoma cell line through interaction with VIP2 receptor. Neuropeptides 1996, 30, 491-496. [CrossRef]

92. Waschek, J.A. VIP and PACAP: Neuropeptide modulators of CNS inflammation, injury, and repair. Br. J. Pharmacol. 2013, 169, 512-523. [CrossRef] [PubMed]

93. Reglodi, D.; Cseh, S.; Somoskoi, B.; Fulop, B.D.; Szentleleky, E.; Szegeczki, V.; Kovacs, A.; Varga, A.; Kiss, P.; Hashimoto, H.; et al. Disturbed spermatogenic signaling in pituitary adenylate cyclase activating polypeptide-deficient mice. Reproduction 2018, 155, 129-139. [CrossRef] [PubMed]

94. Hattori, S.; Takao, K.; Tanda, K.; Toyama, K.; Shintani, N.; Baba, A.; Hashimoto, H.; Miyakawa, T. Comprehensive behavioral analysis of pituitary adenylate cyclase-activating polypeptide (PACAP) knockout mice. Front. Behav. Neurosci. 2012, 6, 58. [CrossRef] [PubMed]

95. Farkas, J.; Kovács, L.Á.; Gáspár, L.; Nafz, A.; Gaszner, T.; Ujvári, B.; Kormos, V.; Csernus, V.; Hashimoto, H.; Reglődi, D. Construct and face validity of a new model for the three-hit theory of depression using PACAP mutant mice on CD1 background. Neuroscience 2017, 354, 11-29. [CrossRef] [PubMed] 
96. Shibasaki, Y.; Hayata-Takano, A.; Hazama, K.; Nakazawa, T.; Shintani, N.; Kasai, A.; Nagayasu, K.; Hashimoto, R.; Tanida, M.; Katayama, T.; et al. Atomoxetine reverses locomotor hyperactivity, impaired novel object recognition, and prepulse inhibition impairment in mice lacking pituitary adenylate cyclase-activating polypeptide. Neuroscience 2015, 297, 95-104. [CrossRef] [PubMed]

97. Kormos, V.; Gaspar, L.; Kovacs, L.A.; Farkas, J.; Gaszner, T.; Csernus, V.; Balogh, A.; Hashimoto, H.; Reglodi, D.; Helyes, Z. Reduced response to chronic mild stress in PACAP mutant mice is associated with blunted FosB expression in limbic forebrain and brainstem centers. Neuroscience 2016, 330, 335-358. [CrossRef] [PubMed]

98. Hashimoto, H.; Shintani, N.; Tanaka, K.; Mori, W.; Hirose, M.; Matsuda, T.; Sakaue, M.; Miyazaki, J.-I.; Niwa, H.; Tashiro, F. Altered psychomotor behaviors in mice lacking pituitary adenylate cyclase-activating polypeptide (PACAP). Proc. Natl. Acad. Sci. USA 2001, 98, 13355-13360. [CrossRef] [PubMed]

99. Takuma, K.; Maeda, Y.; Ago, Y.; Ishihama, T.; Takemoto, K.; Nakagawa, A.; Shintani, N.; Hashimoto, H.; Baba, A.; Matsuda, T. An enriched environment ameliorates memory impairments in PACAP-deficient mice. Behav. Brain Res. 2014, 272, 269-278. [CrossRef] [PubMed]

100. Vaudry, D.; Falluel-Morel, A.; Basille, M.; Pamantung, T.F.; Fontaine, M.; Fournier, A.; Vaudry, H.; Gonzalez, B.J. Pituitary adenylate cyclase-activating polypeptide prevents c2-ceramide-induced apoptosis of cerebellar granule cells. J. Neurosci. Res. 2003, 72, 303-316. [CrossRef] [PubMed]

101. Takei, N.; Skoglösa, Y.; Lindholm, D. Neurotrophic and neuroprotective effects of pituitary adenylate cyclase-activating polypeptide (PACAP) on mesencephalic dopaminergic neurons. J. Neurosci. Res. 1998, 54, 698-706. [CrossRef]

102. Rozzi, S.J.; Borelli, G.; Ryan, K.; Steiner, J.P.; Reglodi, D.; Mocchetti, I.; Avdoshina, V. PACAP27 is protective against tat-induced neurotoxicity. J. Mol. Neurosci. 2014, 54, 485-493. [CrossRef] [PubMed]

103. Aubert, N.; Vaudry, D.; Falluel-Morel, A.; Desfeux, A.; Fisch, C.; Ancian, P.; de Jouffrey, S.; Le Bigot, J.-F.; Couvineau, A.; Laburthe, M. PACAP prevents toxicity induced by cisplatin in rat and primate neurons but not in proliferating ovary cells: Involvement of the mitochondrial apoptotic pathway. Neurobiol. Dis. 2008, 32, 66-80. [CrossRef] [PubMed]

104. Atlasz, T.; Szabadfi, K.; Kiss, P.; Babai, N.; Koszegi, Z.; Tamas, A.; Reglodi, D.; Gabriel, R. PACAP-mediated neuroprotection of neurochemically identified cell types in MSG-induced retinal degeneration. J. Mol. Neurosci. 2008, 36, 97-104. [CrossRef] [PubMed]

105. Han, P.; Tang, Z.; Yin, J.; Maalouf, M.; Beach, T.G.; Reiman, E.M.; Shi, J. Pituitary adenylate cyclase-activating polypeptide protects against $\beta$-amyloid toxicity. Neurobiol. Aging 2014, 35, 2064-2071. [CrossRef] [PubMed]

106. Ohtaki, H.; Nakamachi, T.; Dohi, K.; Shioda, S. Role of PACAP in ischemic neural death. J. Mol. Neurosci. 2008, 36, 16-25. [CrossRef] [PubMed]

107. Armstrong, B.; Abad, C.; Chhith, S.; Cheung-Lau, G.; Hajji, O.; Nobuta, H.; Waschek, J. Impaired nerve regeneration and enhanced neuroinflammatory response in mice lacking pituitary adenylyl cyclase activating peptide. Neuroscience 2008, 151, 63-73. [CrossRef] [PubMed]

108. Watson, M.B.; Nobuta, H.; Abad, C.; Lee, S.K.; Bala, N.; Zhu, C.; Richter, F.; Chesselet, M.-F.; Waschek, J.A. PACAP deficiency sensitizes nigrostriatal dopaminergic neurons to paraquat-induced damage and modulates central and peripheral inflammatory activation in mice. Neuroscience 2013, 240, 277-286. [CrossRef] [PubMed]

109. Uchida, D.; Arimura, A.; Somogyvari-Vigh, A.; Shioda, S.; Banks, W.A. Prevention of ischemia-induced death of hippocampal neurons by pituitary adenylate cyclase activating polypeptide. Brain Res. 1996, 736, 280-286. [CrossRef]

110. Reglodi, D.; Somogyvari-Vigh, A.; Vigh, S.; Kozicz, T.; Arimura, A. Delayed systemic administration of PACAP38 is neuroprotective in transient middle cerebral artery occlusion in the rat. Stroke 2000, 31, 1411-1417. [CrossRef] [PubMed]

111. Reglodi, D.; Tamas, A.; Somogyvari-Vigh, A.; Szanto, Z.; Kertes, E.; Lenard, L.; Arimura, A.; Lengvari, I. Effects of pretreatment with PACAP on the infarct size and functional outcome in rat permanent focal cerebral ischemia. Peptides 2002, 23, 2227-2234. [CrossRef]

112. Lamine, A.; Letourneau, M.; Doan, N.D.; Maucotel, J.; Couvineau, A.; Vaudry, H.; Chatenet, D.; Vaudry, D.; Fournier, A. Characterizations of a synthetic pituitary adenylate cyclase-activating polypeptide analog displaying potent neuroprotective activity and reduced in vivo cardiovascular side effects in a Parkinson's disease model. Neuropharmacology 2016, 108, 440-450. [CrossRef] [PubMed] 
113. Tamas, A.; Lubics, A.; Lengvari, I.; Reglodi, D. Protective effects of PACAP in excitotoxic striatal lesion. Ann. N. Y. Acad. Sci. 2006, 1070, 570-574. [CrossRef] [PubMed]

114. Polanco, M.J.; Parodi, S.; Piol, D.; Stack, C.; Chivet, M.; Contestabile, A.; Miranda, H.C.; Lievens, P.M.; Espinoza, S.; Jochum, T.; et al. Adenylyl cyclase activating polypeptide reduces phosphorylation and toxicity of the polyglutamine-expanded androgen receptor in spinobulbar muscular atrophy. Sci. Transl. Med. 2016, 8, 370ra181. [CrossRef] [PubMed]

115. Kovesdi, E.; Tamas, A.; Reglodi, D.; Farkas, O.; Pal, J.; Toth, G.; Bukovics, P.; Doczi, T.; Buki, A. Posttraumatic administration of pituitary adenylate cyclase activating polypeptide in central fluid percussion injury in rats. Neurotox. Res. 2008, 13, 71-78. [CrossRef] [PubMed]

116. Hori, M.; Nakamachi, T.; Rakwal, R.; Shibato, J.; Ogawa, T.; Aiuchi, T.; Tsuruyama, T.; Tamaki, K.; Shioda, S. Transcriptomics and proteomics analyses of the PACAP38 influenced ischemic brain in permanent middle cerebral artery occlusion model mice. J. Neuroinflamm. 2012, 9, 256. [CrossRef] [PubMed]

117. Chen, Y.; Samal, B.; Hamelink, C.R.; Xiang, C.C.; Chen, Y.; Chen, M.; Vaudry, D.; Brownstein, M.J.; Hallenbeck, J.M.; Eiden, L.E. Neuroprotection by endogenous and exogenous PACAP following stroke. Regul. Pept. 2006, 137, 4-19. [CrossRef]

118. Araki, T.; Milbrandt, J. Ninjurin, a novel adhesion molecule, is induced by nerve injury and promotes axonal growth. Neuron 1996, 17, 353-361. [CrossRef]

119. Brifault, C.; Gras, M.; Liot, D.; May, V.; Vaudry, D.; Wurtz, O. Delayed pituitary adenylate cyclase-activating polypeptide delivery after brain stroke improves functional recovery by inducing $\mathrm{m} 2 \mathrm{microglia} / \mathrm{macrophage}$ polarization. Stroke 2015, 46, 520-528. [CrossRef] [PubMed]

120. Rogalla, T.; Ehrnsperger, M.; Preville, X.; Kotlyarov, A.; Lutsch, G.; Ducasse, C.; Paul, C.; Wieske, M.; Arrigo, A.P.; Buchner, J.; et al. Regulation of Hsp27 oligomerization, chaperone function, and protective activity against oxidative stress/tumor necrosis factor alpha by phosphorylation. J. Biol. Chem. 1999, 274, 18947-18956. [CrossRef] [PubMed]

121. Rhee, S.G.; Kang, S.W.; Chang, T.S.; Jeong, W.; Kim, K. Peroxiredoxin, a novel family of peroxidases. IUBMB Life 2001, 52, 35-41. [CrossRef] [PubMed]

122. Shendelman, S.; Jonason, A.; Martinat, C.; Leete, T.; Abeliovich, A. DJ-1 is a redox-dependent molecular chaperone that inhibits alpha-synuclein aggregate formation. PLoS Biol. 2004, 11, e362.

123. Hayes, J.D.; Flanagan, J.U.; Jowsey, I.R. Glutathione transferases. Annu. Rev. Pharmacol. Toxicol. 2005, 45, 51-88. [CrossRef] [PubMed]

124. Brifault, C.; Vaudry, D.; Wurtz, O. The neuropeptide PACAP, a potent disease modifier candidate for brain stroke treatment. In Pituitary Adenylate Cyclase Activating Polypeptide-PACAP; Springer: Cham, Switzerland, 2016; Volume 11, pp. 583-606.

125. Reglodi, D.; Vaczy, A.; Rubio-Beltran, E.; MaassenVanDenBrink, A. Protective effects of PACAP in ischemia. J. Headache Pain 2018, 19, 19. [CrossRef] [PubMed]

(C) 2018 by the authors. Licensee MDPI, Basel, Switzerland. This article is an open access article distributed under the terms and conditions of the Creative Commons Attribution (CC BY) license (http://creativecommons.org/licenses/by/4.0/). 